\title{
СРАВНИТЕЛЬНАЯ ОЦЕНКА СТАНДАРТНЫХ, КОМПОЗИТНЫХ И «ОБЛЕГЧЕННЫХ» СИНТЕТИЧЕСКИХ ПРОТЕЗОВ, ПРИМЕНЯЕМЫХ ДЛЯ ГЕРНИОПЛАСТИКИ (ЭКСПЕРИМЕНТАЛЬНАЯ РАБОТА)
}

\author{
(С Шестаков А.Л., Федоров Д.Н., Иванчик И.Я., Боева И.А., Битаров Т.Т.
}

\author{
Российский научный центр хирургии имени академика Б.В. Петровского, Москва \\ E-mail: hernia2009@mail.ru
}

\begin{abstract}
Целью нашего экспериментального исследования являлась оценка особенностей формирования соединительнотканного рубца при использовании различных видов синтетических протезов для герниопластики. В статье представлены результаты морфологического и иммуногистохимического исследования в эксперименте на 180 белых крысах, проводимого с целью изучения биосовместимости синтетических полимеров из полипропилена, сравнения тканевой реакции передней брюшной стенки животных и сроков образования соединительной ткани в зоне имплантации эндопротезов. Оценка скорости «прорастания» в тканях тяжелого и «облегченного» полипропиленовых и композитного протезов позволила обосновать и сформулировать клинические рекомендации для больных, перенесших протезирующую герниопластику с использованием различных синтетических сеток.

Ключевые слова: грыжесечение, эксперимент, полипропиленовые сетчатые протезы, композитные сетчатые протезы, гистологическое исследование, иммуногистохимия.
\end{abstract}

\section{COMPARATIVE EVALUATION OF STANDARD, COMPOSITE AND "LIGHTWEIGHT" SYNTHETIC PROSTHESES FOR HERNIOPLASTY (EXPERIMENTAL WORK) \\ Shestakov A.L., Fedorov D.N., Ivanchik I.Ja., Boeva I.A., Bitarov T.T.}

Russian Scientific Center of Surgery named after Academician B.V. Petrovsky, Moscow

The purpose of our experimental study was to evaluate the features of the formation of connective tissue scar when using various types of synthetic prostheses for hernioplasty. The article presents the results of morphological and immunohistochemical studies during an experiment with 180 white rats conducted to study the biocompatibility of synthetic polymers from polypropylene, comparison of the tissue response of the anterior abdominal wall of animals and the timing of the formation of connective tissue in the implantation zone of endoprostheses. Evaluation of the rate of "germination" in the tissues of heavy and "lightweight" polypropylene and composite prostheses allowed to substantiate and formulate clinical recommendations for patients with prosthetic hernioplasty using various synthetic nets.

Keywords: hernia repair, experiment, polypropylene mesh prosthesis, composite mesh prosthesis, histological examination, immunohistochemistry.

В настоящее время наблюдается тенденция неуклонного роста количества грыжесечений, выполняемых одномоментно с пластикой синтетическими эксплантатами и заменяющих традиционные методики ввиду малой эффективности последних $[1,6,10]$. Вместе с тем количество больных с диагнозом грыжи передней брюшной стенки продолжает оставаться очень высоким и достигает по некоторым данным 7\% от всего взрослого населения планеты. При этом хирургическая активность в отношении пациентов явно недостаточна: при общей потребности выполнения до полумиллиона герниопластик в год в России их число не превышает 150-180 тысяч операций. Перспективным следует считать внедрение в клиническую практику лечения грыж новых хирургических методик, основанных на применении синтетических полимеров $[3,5,8]$. В настоящее время широко применяются «тяжелые» сетчатые эксплантаты из полипропилена, «облегченные» комбинированные сетки из пролена и викрила или монокрила, сетки из полиэфирных нитей. В то же время начато производство «облегченных» сеток, состоящих исключительно из полипропилена $[4,9]$.

Однако большинство используемых в настоящее время синтетических материалов, являясь инородным телом, способствуют поддержанию воспалительной реакции в ране в силу недостаточной биологической инертности или несоответствующей структуры [7].

\section{МАТЕРИАЛЫ И МЕТОДЫ ИССЛЕДОВАНИЯ}

С целью изучения биосовместимости синтетических полимеров из полипропилена сравнивали тканевую реакцию передней брюшной стенки животных и сроки образования соединительной ткани в зоне имплантации эндопротезов. В исследовании использовались стандартные полипропиленовые («тяжелые») и композитные («UltraPro») сетчатые протезы (фирма «Ethicon» компании «Johnson\&Johnson», США), а также облегченные 
полипропиленовые протезы («Optilene Mesh LP», фирма «B.BRAUN », Германия) (табл. 1).

Эксперименты проведены на 180 крысах обоего пола весом около 150-170 г. Животные были распределены на 3 группы (согласно числу видов исследуемого синтетического материала), по 60 животных в группе. Так как нас интересовала тканевая реакция на сетчатый протез как в раннем, так и в отдаленном послеоперационном периодах, в качестве контрольных были выбраны 3, 7 и 14 сутки после оперативного вмешательства и 60, 180 и 360 сутки соответственно. В эти сроки животных выводили из эксперимента и осуществляли забор биологического материала для дальнейшего гистологического исследования (табл. 2).

Оперативное вмешательство на животных в эксперименте выполнялось по следующей методике. После обезболивания путем внутрибрюшинного введения раствора тиопентала натрия 1,0 шерсть в проекции операционного поля сбривали, кожные покровы четырехкратно обрабатывали раствором йодоната, операционное поле обкладывали стерильным материалом. По средней линии живота рассекали кожу, подкожножировую клетчатку, выделяли передние листки апоневроза прямых мышц живота. Фиксацию полипропиленового сетчатого протеза размерами 2,0x2,0 см осуществляли подшиванием к апоневрозу нитью Prolene 4/0. Рану кожи ушивали отдельными узловыми швами (нить Ethibond 3/0).

Животных выводили из эксперимента на 3,7 , 14, 60, 180 и 360 сутки с момента имплантации полипропиленового сетчатого протеза путем внутрибрюшинного введения больших доз тиопентала натрия.

После выведения животных из эксперимента в стерильных условиях производили забор тканей передней брюшной стенки размерами 2,5х2,5 см из зон имплантации вместе с эндопротезом. Материал доставляли в патологоанатомическое отделение в растворе 10\% нейтрального формалина, где после вырезки выполняли проводку материала с последующей заливкой в парафиновую смесь Histomix (БиоВитрум, Россия) по стандартной методике. Полученные парафиновые блоки использовали для изготовления срезов толщиной 5 мкм, которые затем окрашивали гематоксилином-эозином и пикрофуксином по Ван-Гизону с применением автоматизированного гистостейнера Leica Autosteiner XL ST5010 (Leica Microsystems, Германия). Всего было выполнено исследование 540 биоптатов.

Гистологическое исследование выполняли на микроскопе Leica DM-5000, оснащенном цифровой фотокамерой Leica DFC-490 (Leica Microsystems, Германия), подключенным к графической станции Sony Vaio VGC-RT2SRY (Sony Corporation, Япония) с установленным программным обеспечением Image Scope M (СМА, Россия).

На всех контрольных сроках исследования оценивали характер воспаления, выраженность и распространенность воспалительной реакции, степень зрелости соединительной ткани. Выраженность воспалительной реакции рассчитывалась полуколичественным методом по пятибалльной шкале, где 0 баллов соответствовало отсутствию признаков воспалительной реакции, а 1-4 балла - соответствовали степеням выраженности воспаления.

Кроме того, при гистологическом исследовании проводили оценку выраженности и характера тканевой реакции на имплантат: на ранних сроках (3, 7 и 14 сутки) - формирующуюся грануляционную ткань, степень ее васкуляризации, количество и локализацию фибробластов, наличие фокусов внеклеточного матрикса; на поздних сроках (60, 180 и 360 сутки) - степень зрелости соединительной ткани, ориентацию фибриллярных компонентов внеклеточного матрикса относительно нитей имплантата, а также его состояние (наличие / отсутствие резорбции и т.д.).

Таблица 1

Сравнительная характеристика сетчатых протезов

\begin{tabular}{|c|c|c|c|}
\hline & «Prolene» & «Ultrapro» & «Optilene Mesh LP» \\
\hline Состав эндопротеза & Однородный & Композитный & Однородный \\
\hline Материал & Полипропилен & Полипропилен, полиглекапрон & Полипропилен \\
\hline Структура нити & Монофиламент & Монофиламент & Монофиламент \\
\hline Поверхностная плотность & $72 \Gamma / \mathrm{M}^{2}$ & $28 \Gamma / \mathrm{M}^{2}$ & $36 \Gamma / \mathrm{M}^{2}$ \\
\hline
\end{tabular}

Таблица 2

Распределение животных по сериям эксперимента

\begin{tabular}{|l|c|c|c|c|c|c|c|}
\hline \multicolumn{1}{|c|}{ Материал } & 3 сут. & 7 сут. & 14 сут. & 60 сут. & 180 сут. & 360 сут. & ВСЕГО \\
\hline «Prolene» & 10 & 10 & 10 & 10 & 10 & 10 & 60 \\
\hline «Ultrapro» & 10 & 10 & 10 & 10 & 10 & 10 & 60 \\
\hline «Optilene Mesh LP» & 10 & 10 & 10 & 10 & 10 & 10 & 60 \\
\hline
\end{tabular}


Статистические вычисления осуществлялись с помощью программного обеспечения Microsoft Exel 2013, Statistica 6.0. При статистическом анализе производился расчет средней величины количественных показателей $(\mathrm{M})$, стандартного отклонения (m), коэффициента корреляции Пирсона (r), критерия достоверности Стьюдента.

Оценку степени выраженности воспалительной реакции на основании использованной балльной системы проводили во всех группах на всех контрольных сроках исследования.

Имммуногистохимическое исследование проводили на парафиновых срезах толщиной 4 мкм, нанесенных на стекла с адгезивным (поли-Л-лизиновым) покрытием (Menzel, Германия). В качестве метода выявления антигенов использовался непрямой иммунофлюоресцентный метод, что было обусловлено большим удобством и информативностью данной методики применительно к задачам проводившегося исследования. Иммунолюминесцентное исследование проводили с использованием универсального лабораторного микроскопа Leica DM-5000 в режиме IL (иммунолюминисценция) с соответствующим набором барьерных фильтров. Изображения получали при помощи подключенной к микроскопу цифровой фотокамеры Leica DFC-490 (Leica Microsystems, Германия); сохранение и обработка изображений проводилась при помощи графической станции Sony Vaio VGC-RT2SRY (Sony Corporation, Япония) с установленным программным обеспечением Image Scope M (СМA, Россия).

При иммуногистохимическом исследовании применяли поликлональные кроличьи антитела к коллагену I типа крысы (RAQ C11, ИМТЕК, Россия) и коллагену III типа крысы (RAQ C33, ИМТЕК, Россия); мышиные моноклональные антитела к фибронектину (MGH Fne, ИМТЕК, Россия). В качестве системы визуализации использовали вторичные антитела, конъюгированные с ФИТЦ, против иммуноглобулинов $\mathrm{IgG}$, IgA, IgM кролика (f-GAR Iss, ИМТЕК, Россия) для визуализации продуктов иммуногистохимической реакции с первичными антителами к коллагенам I и III типов; вторичные антитела конъюгированные с родамином к иммуноглобулинам IgG, IgA, IgM мыши (r-GAM Iss, ИМТЕК, Россия) - для визуализации продуктов иммуногистохимической реакции с первичными антителами к фибронектину.

Протокол иммуногистохимического исследования был адаптирован к использованию иммунофлюоресцентного метода на парафиновых срезах согласно рекомендациям, опубликованным Н.И Кондриковым с соавт. [2], включающих в себя следующие основные этапы:
- депарафинацию срезов (по стандартной методике);

- инкубацию срезов с протеиназой К во влажной камере при $37^{\circ} \mathrm{C}-30$ мин;

- инкубацию срезов с первичными антителами - 45 мин во влажной камере при $37^{\circ} \mathrm{C}$;

- инкубацию срезов с вторичными антителами, конъюгированными с флюоресцентной меткой - 30 мин во влажной камере при $37^{\circ} \mathrm{C}$.

Для исключения ложноположительных и ложноотрицательных результатов ставились позитивные (внутренний позитивный контроль оценка наличия продуктов реакции в структурах, заведомо содержащих определяемый антиген) и негативные контроли (с заменой первичных антител $0,1 \%$ раствором BSA (DAKO, Дания)).

При интерпретации результатов оценивали выраженность экспрессии антигенов (по интенсивности свечения) при помощи полуколичественного метода: « - » - экспрессия маркера отсутствует; «-/+ »- неравномерная, очаговая слабоположительная экспрессия; «+ »- слабовыраженная экспрессия маркера; 《++ »- умеренно выраженная экспрессия маркера; «+++ »- хорошо выраженная экспрессия маркера. Кроме того, учитывали локализацию и распределение иммунореактантов в препарате.

При анализе результатов иммуногистохимического исследования оценивали выраженность экспрессии антигенов (по интенсивности свечения) при помощи полуколичественного метода, при котором выполняли распределение показателя от отсутствия признака до его хорошей выраженности.

\section{РЕЗУЛЬТАТЫ ИССЛЕДОВАНИЯ И ИХ ОБСУЖДЕНИЕ}

Мы не получили существенных и достоверных $(p>0,05)$ различий степени выраженности воспаления в образцах разных групп, полученных в ранние сроки после имплантации. В отдаленные сроки (от 60 до 180 суток) лишь в группе, где была использована тяжелая полипропиленовая сетка, сохранялись незначительные признаки воспалительной реакции. Различия не были достоверны $(\mathrm{p}>0,05)$.

В первые трое суток выявлена хорошо выраженная экспрессия фибронектина во всех трех группах, а также отмечено появление коллагенов I и III типов (слабовыраженная неравномерная очаговая экспрессия) в группах, где были имплантированы композитный и легкий полипропиленовый протезы. В группе животных, где использовался тяжелый полипропиленовый протез, появления коллагена на этих сроках выявлено не было (рис. 1). 


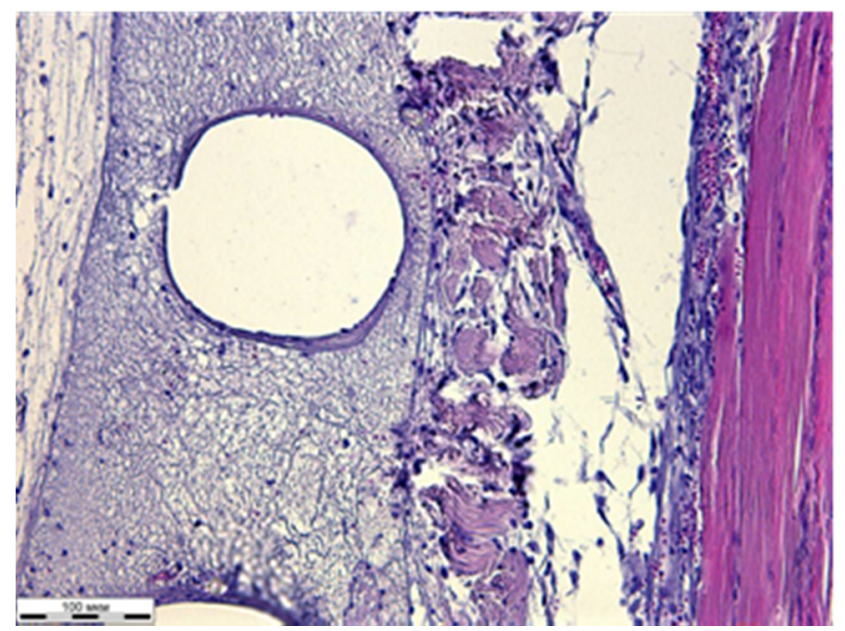

A.

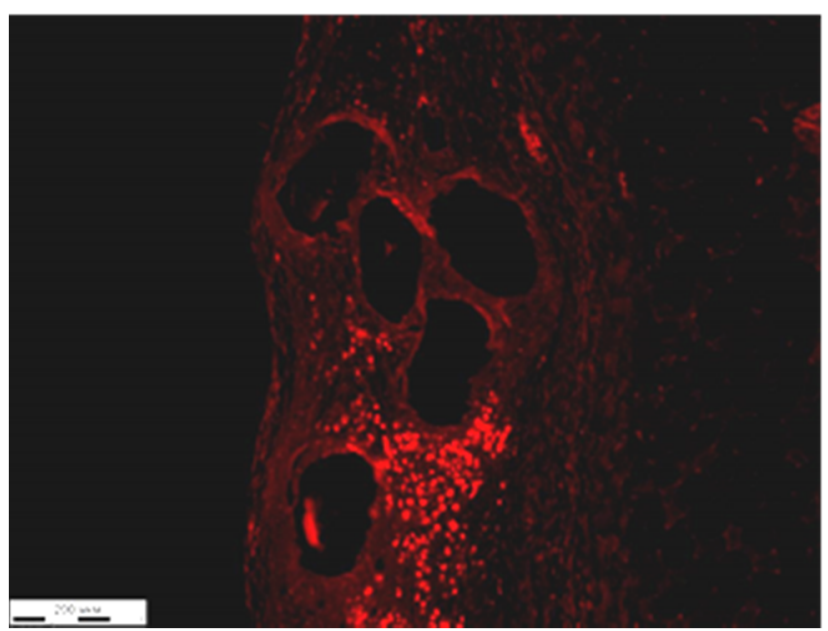

Б.

Рис. 1. Изменения тканей передней брюшной стенки крысы на 3-и сутки после имплантации полипропиленового сетчатого протеза. А. - Фибрин вокруг нитей протеза, полиморфноядерные лейкоциты и макрофаги в составе инфильтрата, единичные фибробласты. Окраска гематоксилином и эозином х200. Б. - Диффузная экспрессия фибронектина в составе экссудата вокруг нитей протеза. Иммунолюминесцентный метод. х100.

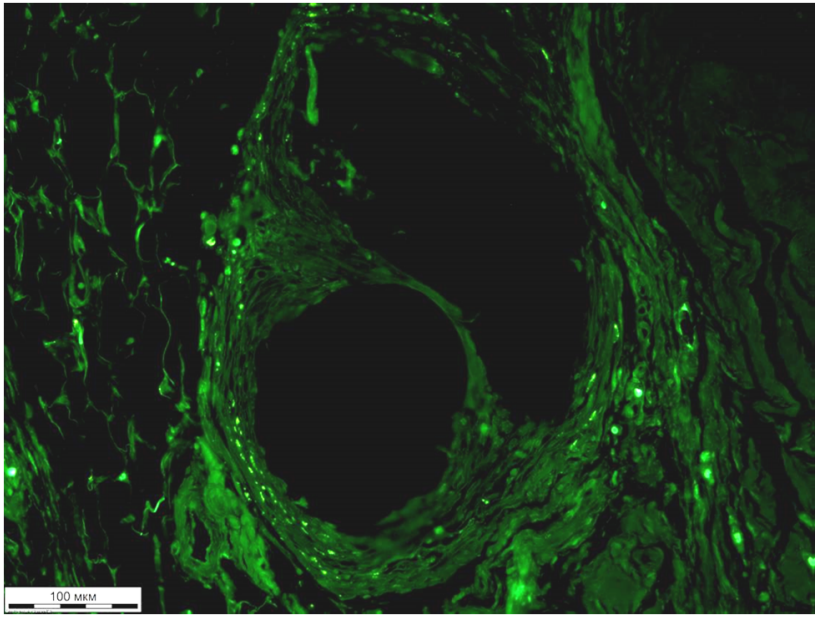

A.

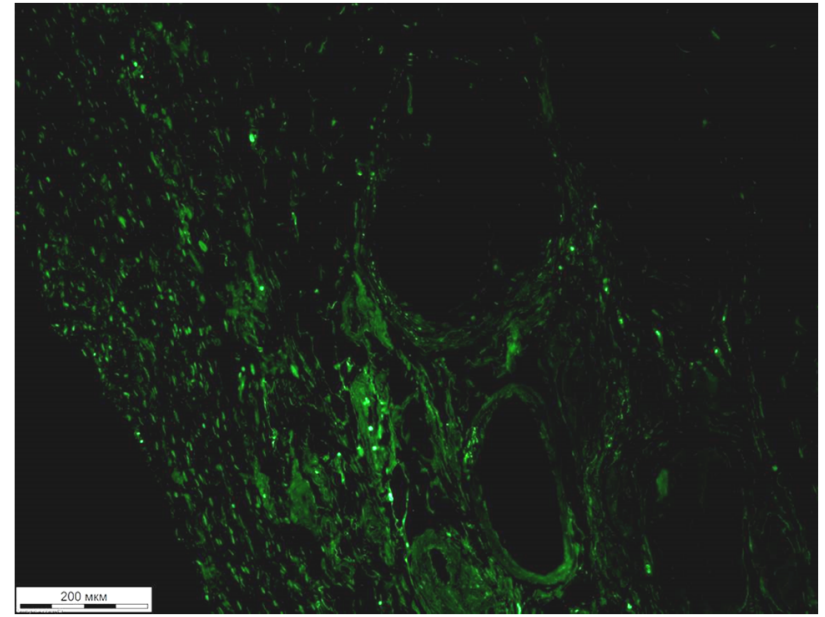

Б.

Рис. 2. 7-е сутки после имплантации полипропиленового сетчатого протеза. А. - Умеренно выраженная экспрессия коллагена I типа, с усилением свечения преимущественно вокруг нитей протеза. Б. - Слабовыраженная, диффузная экспрессия коллагена III типа. Иммунолюминесцентный метод. х100.

Существенные различия в распределении степени выраженности экспрессии коллагенов по исследованным группам выявлены уже на 7-е сутки после операции. В частности, если уровень экспрессии коллагена I типа в группах с композитной и легкой сетками фактически не изменился, то степень экспрессии этого типа коллагена после имплантации тяжелого полипропиленового протеза выросла до степени умеренной выраженности $(\mathrm{p}<0,05)$. Для коллагена III типа отмечена аналогичная тенденция, хотя и меньшей степени выраженности $(\mathrm{p}>0,05)$ (рис. 2).

Через 14 суток после имплантации синтетических протезов на фоне снижения выраженности экспрессии фибронектина отмечено дальнейшее интенсивное возрастание уровня коллагенов I и III типов во всех исследованных группах.
Таким образом, ранняя реакция тканей на имплантацию различных протезов была схожей, хотя и отличалась скоростью появления и формирования различных типов коллагенов (рис. 3).

При оценке степени выраженности антигенов в отдаленном послеоперационном периоде отмечено продолжение усиления экспрессии коллагенов I и III типов и снижение экспрессии фибронектина.

Через 60 суток после имплантации слабовыраженная и умеренно выраженная экспрессия коллагенов отмечалась для всех видов протезов, различия были недостоверны (p>0,05) (рис. 4). 


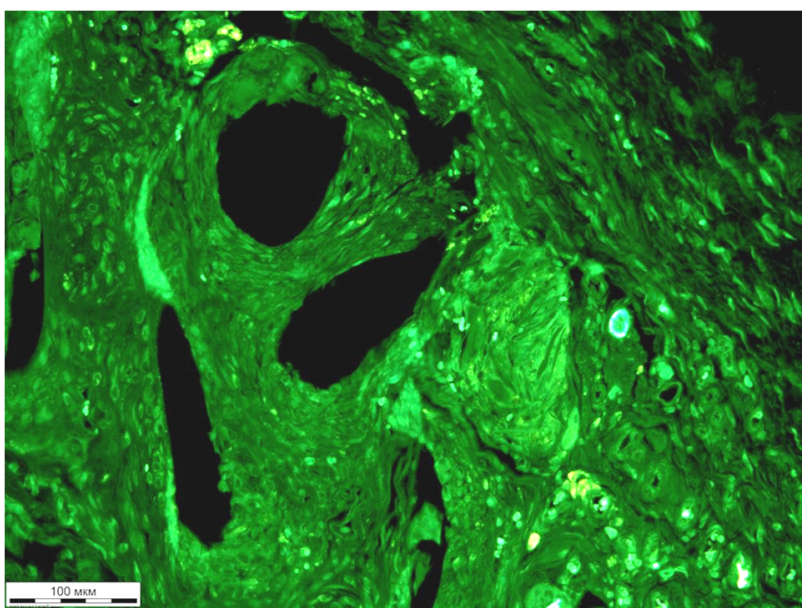

A.

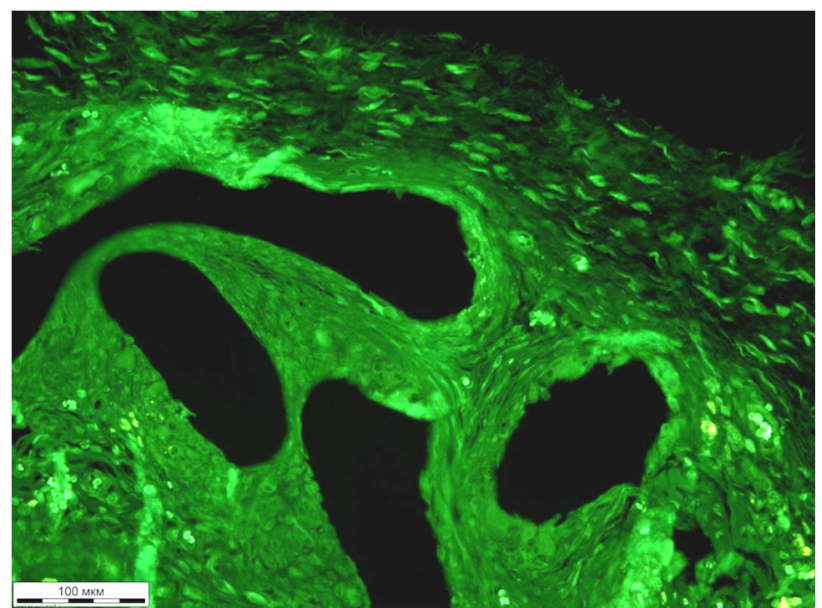

Б.

Рис. 3. 14-е сутки после имплантации полипропиленового сетчатого протеза. А. - Умеренно выраженная экспрессия коллагена I типа. Б. - Умеренно выраженная экспрессия коллагена III типа, с усилением свечения преимущественно вокруг нитей протеза. Иммунолюминесцентный метод. х200.

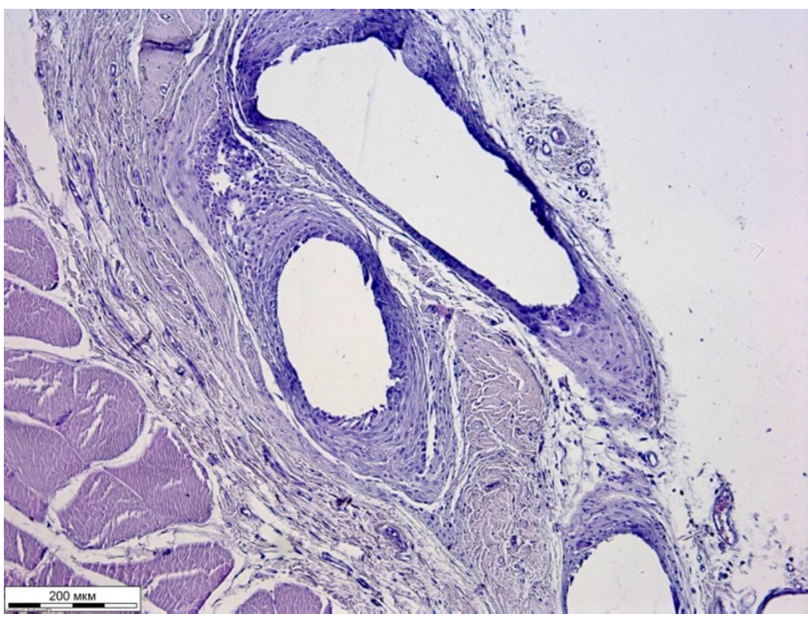

A.

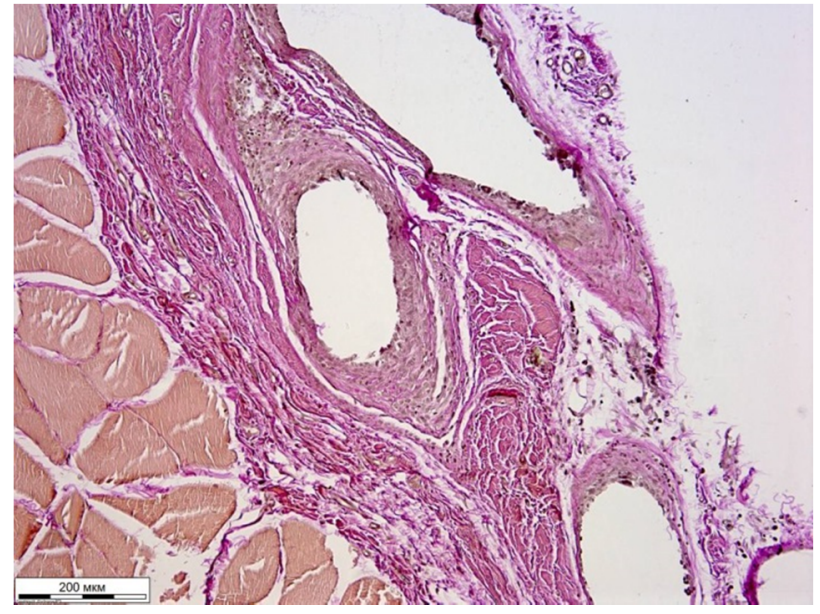

Б.

Рис. 4. Изменения тканей передней брюшной стенки крысы на 60-е сутки после имплантации полипропиленового сетчатого протеза. Зрелая соединительная ткань с волокнами, циркулярно-ориентированными вокруг нитей протеза. Слабовыраженная лимфогистиоцитарная инфильтрация с гигантскими многоядерными клетками инородных тел и эпителиодными клетками. А. - Окраска гематоксилином и эозином. х100. Б. - Окраска пикрофуксином по Ван-Гизону. х100.

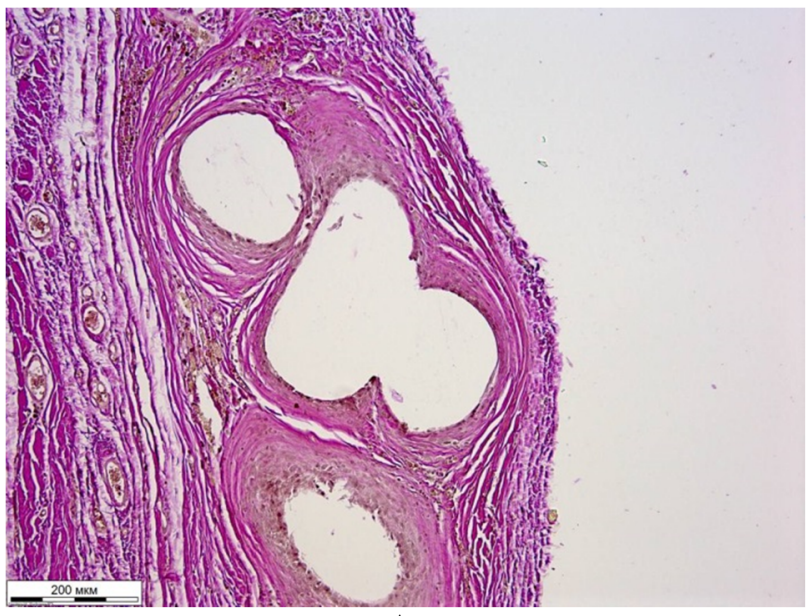

A.

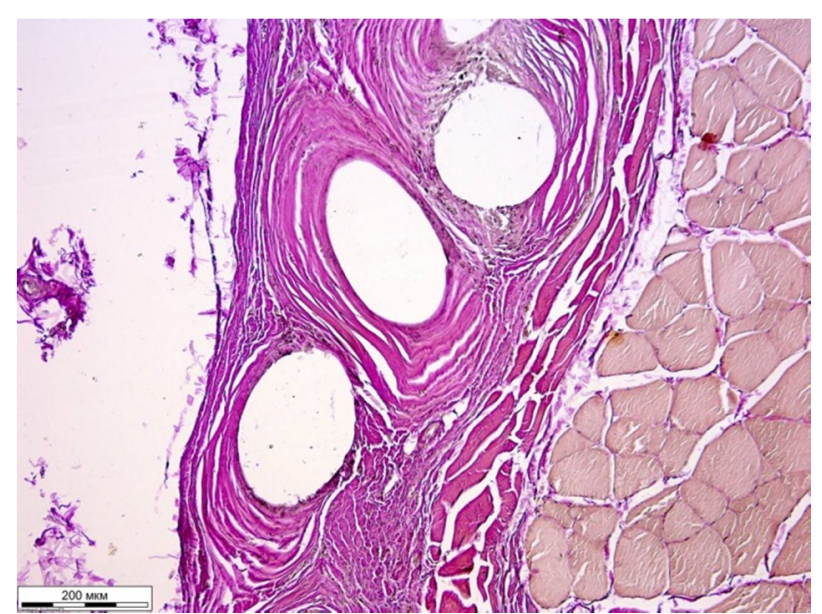

Б.

Рис. 5. А. - 180-е сутки после имплантации полипропиленового сетчатого протеза. Б. - 360-е сутки после имплантации полипропиленового сетчатого протеза. Окраска пикрофуксином по Ван-Гизону. х100. 
Таблица 3

Выраженность экспрессии антигенов фибронектина и коллагенов I и III типов

\begin{tabular}{|c|c|}
\hline & Выраженность воспалительной реакции в баллах (ср.) \\
\hline «Ultrapro» (3 суток) & 2 \\
\hline «Optilene Mesh LP» (3 суток) & 1 \\
\hline «Prolene» (3 сутки) & 2 \\
\hline «Ultrapro» (7 суток) & 2 \\
\hline «Optilene Mesh LP» (7 суток) & 2 \\
\hline «Prolene» $(7$ сутки $)$ & 2 \\
\hline «Ultrapro» (14 суток) & 1 \\
\hline «Optilene Mesh LP» (14 суток) & 1 \\
\hline «Prolene» (14 суток) & 1 \\
\hline «Ultrapro» (60 суток) & 0 \\
\hline «Optilene Mesh LP» (60 суток) & 0 \\
\hline «Prolene» (60 суток) & 1 \\
\hline «Ultrapro» $(180$ суток $)$ & 0 \\
\hline «Optilene Mesh LP» (180 суток) & 0 \\
\hline «Prolene» $(180$ суток $)$ & $0-1$ \\
\hline «Ultrapro» (360 суток) & 0 \\
\hline «Optilene Mesh LP» (360 суток) & 0 \\
\hline «Prolene» (360 суток) & 0 \\
\hline
\end{tabular}

Следует отметить, что в последующем, на 180 -е и 360 -е сутки, экспрессия коллагена I типа при исследовании образцов с синтетической композитной и легкой полипропиленовой сетками существенно не изменилась. Напротив, при оценке экспрессии маркера этого типа коллагена для тяжелой сетки выявлено ее повышение до уровня хорошо выраженной через полгода после имплантации. Для коллагена III типа уровень экспрессии, сформировавшийся на уровне «слабо/умеренно выраженный» к 60 суткам, сохранился на этом показателе к 180-м и 360-м суткам после начала эксперимента (рис. 5).

Мы получили сходную реакцию, используя различные виды протезов. Во всех случаях экспрессия маркеров антигенов, вначале диффузная, реализовывалась в дальнейшем в более выраженную экспрессию коллагенов I и III типов (табл. 3).

Оценка тканевой реакции с точки зрения сроков фиксации протеза в тканях показала, что на 60-е сутки после начала эксперимента в группе, где был использован тяжелый полипропиленовый протез, в области имплантации выявлены морфологические признаки слабо выраженного продуктивного воспаления. Воспалительной реакции при этом за пределами апоневроза обнаружено не было. Обращает на себя внимание, что соединительная ткань носила характер зрелой и была представлена соединительнотканной капсулой вокруг нитей сетки.

Применение легкой полипропиленовой сетки через 2 месяца после операции продемонстрировало отсутствие воспалительной реакции вокруг нитей сетки с формированием, тем не менее, сла- бо выраженной соединительнотканной капсулы и разрастанием фиброзной ткани в виде муфт по ходу нитей. Необходимая для прочной фиксации сетки продуктивная воспалительная реакция, в исходе характеризующаяся развитием фиброза с формированием соединительнотканной капсулы вокруг нитей протеза и септ, врастающих в просвет ячеек, при использовании протеза такого типа отмечена лишь через 180 суток после выполненного вмешательства.

На 60-е сутки после имплантации композитного протеза «Ultrapro» выявлено незначительное количество фиброзной ткани вокруг нитей сетки, и, что особенно важно, отсутствие формирования соединительнотканных септ в ее ячейках на фоне незначительных признаков воспалительной реакции. Обращает на себя внимание то обстоятельство, что гистологически на 180 -е сутки после имплантации композитного сетчатого протеза в большинстве случаев отмечено отсутствие воспалительной реакции и компактное размещение зрелой соединительной ткани вокруг нитей протеза с формированием муфтообразных структур за счет циркулярно-ориентированных фибрилл коллагена. Важно, что соединительнотканные септы в просвете ячеек сетки не формировались и на этом сроке. Не отмечено прорастания ячеек сетки и к концу эксперимента, то есть к 360 суткам.

При иммуногистохимическом исследовании на 60-е сутки отмечалась выраженная экспрессия коллагена I типа в группе, где был применен тяжелый протез, и умеренная и слабо выраженная экспрессия коллагена I при оценке протезов мень- 
шей поверхностной плотности. Экспрессия коллагена III типа во всех группах была умеренно выраженной.

К 180-м суткам оба типа коллагена распределялись с формированием ячеек и септ между нитями, а к 360-м суткам - заполняли их, локализуясь в виде муфт вокруг нитей протеза для всех образцов, где были использованы протезы из полипропилена. Обращает на себя внимание то обстоятельство, что при применении композитного протеза соединительнотканные септы в просвете ячеек сетки не формировались ни к 180-м суткам, ни через год после имплантации.

Таким образом, воспалительно-репаративная реакция с образованием рубца сопровождала имплантацию протезов всех трех использованных видов. Реакция на имплантацию протезов как в ранние сроки после начала эксперимента, так и в отдаленные была по основным признакам сходной. Использование тяжелого полипропиленового протеза приводило к более выраженному воспалению и к формированию рубца более «грубого» за счет содержания большого количества коллагена I типа. Уменьшение количества нерассасывающегося материала (полипропилена) в тканях создавало условия для более быстрого стихания воспаления и в то же время к формированию более «мягкого» рубца с умеренным содержанием коллагена I типа и в более поздние сроки. Реакция на композитный протез «Ultrapro» продемонстрировала морфологические изменения, говорящие о, возможно, недостаточно прочной фиксации протеза, что обусловлено более высоким содержанием в составе формируемой соединительной ткани коллагена III типа, имеющего меньшую механическую прочность.

Впервые в эксперименте была проведена морфологическая и иммуногистохимическая оценка характера тканевой реакции на имплантацию различных видов синтетических материалов, применяемых для герниопластики. На основании изучения результатов объемного экспериментального материала продемонстрированы особенности тканевой реакции с оценкой динамики образования коллагенов I и III типов, а также фибронектина после имплантации полипропиленовых сетчатых протезов различной поверхностной плотности, а также композитного протеза как в ранние, так и в отдаленные сроки после начала экспериментального исследования.

В работе дана морфологическая оценка качества сформированного рубца в зависимости от вида использованного синтетического материала, в динамике изучен характер и степень прорастания сетчатого протеза соединительной тканью, показано, что последней стадией реакции окру- жающих тканей на полипропиленовый протез является формирование полноценного рубца независимо от объема имплантированного нерассасывающегося материала и варьирует лишь по количеству образующейся вокруг нитей протеза фиброзной ткани. Оценка скорости «прорастания» в тканях тяжелого и «облегченного» полипропиленовых и композитного протезов позволила обосновать и сформулировать клинические рекомендации для больных, перенесших протезирующую герниопластику с использованием различных синтетических сеток.

\section{ЛИТЕРАТУРА}

1. Егиев В.Н., Чижов Д.В. Проблемы и противоречия «ненатяжной» герниопластики // Герниология. 2004. - № 4. - C. 3-7.

2. Кондриков Н.И., Шамаракова М.В., Горбачева Ю.В. Значение иммуногистохимического определения биомаркеров плоскоклеточных интраэпителиальных поражений шейки матки // Акушерство и гинекология. - 2010. - № 6. - С. 44-48.

3. Мамедов Р.А. Морфологическая оценка местной реакции организма при применении сетчатых материалов для протезирования передней брюшной стенки // Новости хирургии. - 2013. - Т. 21, № 1. C. 23-28.

4. Нетяга А.А., Парфенов А.О., Нутфуллина Г.М., Жуковский В.A. Легкие или композитные эндопротезы для герниопластики; выбор материала на основании экспериментального изучения их биосовместимых свойств // Соврем. проблемы науки и образования. - 2013. - № 5. - С. 370.

5. Суковатых Б.С., Валуйская Н.М., Нетяга А.А., Герасимчук Е.В., Жуковский В.А. Эндопротезирование брюшной стенки с лифтингом мышечно-апоневротических тканей гипогастральной области в лечении вентральных грыж больших размеров // Курск. науч.-практ. вестн. «Человек и его здоровье». - 2012. - № 3. - С. 88-92.

6. Тимошин А.Д., Шестаков А.Л., Загорулько О.И., Инаков А.Г. Оценка функции мышщ передней брюшной стенки после герниопластики // Бюллетень сибирской медицины. - 2007. - № 3. - С. 62 - 64.

7. Шапошников В.И. Лечение гигантских послеоперационных грыж // Хирургия. - 2000. - № 12. C. 30-33.

8. Anurov M.V., Titkova S.M., Oettinger A.P. Biomechanical compatibility of surgical mesh and fascia being reinforced: dependence of experimental hernia defect repair results on anisotropic surgical mesh positioning // Hernia. - 2012. - Vol. 16, N 2. P. 199-210. - doi: 10.1007/s10029-011-0877-y.

9. Gonzalez R., Ramshaw B.J. Comparison of tissue integration between polyester and polypropylene prostheses in the preperitoneal space // Am. Surg. - 2003. - Vol. 69, N 6. - P. 471-476.

10. Read R. C. Milestones in the history of hernia surgery: prosthetic // Hernia. - 2004. - Vol. 8, N 1. - P. 8-14. 